\title{
Production of probiotic Cajá fruit (Spondias mombin) powder using Bifidobacterium animalis ssp. lactis B94 via spouted bed
}

\author{
Thais Jaciane ARAUJO RODRIGUES ${ }^{1 *}$ (D), Aline PACHECO ALBUQUERQUE ${ }^{1}$, Layanne RODRIGUES DA SILVA², \\ Hanndson ARAUJO SILVA ${ }^{3}$, Matheus Augusto DE BITTENCOURT PASQUALI ${ }^{2}$, Gilmar TRINDADE DE ARAÚJO², \\ Ana Paula TRINDADE ROCHA ${ }^{1,2}$
}

\begin{abstract}
Probiotic bacteria inclusion on fruit pulp is an exceptional alternative for the production and innovation of functional foods. Therefore, the present work aims to study the drying of Caja (Spondias mombin) pulp added with Bifidobacterium animalis ssp. lactis using a spouted bed. An experimental design comprising 11 experiments was used on the drying, varying the inlet temperature $\left(50{ }^{\circ} \mathrm{C}, 60^{\circ} \mathrm{C}\right.$, and $\left.70^{\circ} \mathrm{C}\right)$, the maltodextrin concentration $(2.5,5.0$, and $7.5 \% \mathrm{wt})$ and inulin concentration $(2.5$, 5.0 , and $7.5 \% \mathrm{wt})$. The dependent variables studied in our work were the process yield and the number of viable cells. The liquid fruit pulp presented physicochemical conditions for bacteria growth and high content of bioactive compounds. Results revealed that lower inlet temperature in combination with lower concentrations of maltodextrin and inulin resulted in a powder with a higher number of viable cells. Even though temperature degradation is a critical factor for product quality while using drying processes, it was considered that the process was efficient because of the high cell viability, which is the critical factor to consider the product as probiotic.
\end{abstract}

Keywords: Bifidobacterium animalis ssp. Lactis; experimental design; cell viability; process yield.

Practical Application: We declare that food quality and safety standards were established and applied, as well as the guarantee of fair practices in order to avoid waste and losses, rescuing current standards and legislation, spreading the immeasurable wealth of the product obtained.

\section{Introduction}

Regional product valorization is intended to increase the consumption of local products by enhancing sensorial and functional properties. Consequently, the local products have their economical and nutritional value increased. Research for innovative food products with abundant availability and using different substances is vital to supply consumer demand and expectations (Joshi et al., 2018).

Cajá (Spondias mombin) is considered a tropical and exotic fruit that belongs to the genre Spondias. Approximately, Caja processing generates $50 \%$ of solid wastes comprising peels and seeds, while the pulp represents $50 \%$ of the fruit weight, yielding a reasonable quantity for valorization. Caja fruit is considered a substantially nutritional. Caja contains a high content of bioactive compounds, such as, vitamin C, pro-vitamin A, phenolic and antioxidant compounds (Mattietto \& Matta, 2011). Per $100 \mathrm{~g}$, the Caja pulp contains an energetic value of approximately $50 \mathrm{kCal}$, $6 \mathrm{~g}$ of carbohydrates, and approximately $2 \mathrm{~g}$ of insoluble fiber. These values are evidence of fruit relevance and highlight its nutritional value (Chaves, 2019).

The need to develop fruit juices added with probiotics, representing an option to diversify products for the industry, using a new plant matrix, brings a new categorization of functional food, defined as any food or food ingredient that can provide a healthy benefit beyond the traditional nutrients they contain (Silva et al., 2018; Albuquerque et al., 2021).

Considering the nutritional availability and its production, the Caja can be a reasonable source for a probiotic product with functional properties. The probiotics are considered by the Food and Agriculture Organization (Food and Agriculture Organization, 2002) as "live microorganism when administered in adequate amounts contribute a health benefit on the host" (Dincer \& Kivanc, 2020). For such, a viable means for preparation and conservation of its viability in the digestive tract ecosystem is critical for its effectiveness. Probiotic bacteria represent a significant interest in the production of probiotic food-however, bacteria stirp such as Bifidobacterium animalis ssp. lactis still have little research. Probiotics can produce effects capable of inducing pro-inflammatory, anti-inflammatory, or secretory reactions that may inhibit carcinogenesis (Rusu et al., 2019). According to Brasil (2019) and Food and Agriculture Organization (2006), the Bifidobacterium dosage should be in the range of $10^{8}$ a $10^{9} \mathrm{CFU} / \mathrm{g}$ for proper efficiency. 
Fruit pulps are highly perishable sub-products where moisture removal is crucial for its preservation and consumption at any period of the year. Thus, to avoid spoilage and increase its market value, a drying process is required to decrease water activity and thus microbial growth (Ferreira et al., 2019). The spouted bed is a drying method that combines instant and simultaneous mass and heat transfer with adequate control of the relative humidity (Rocha et al., 2018). Moreover, drying with a spouted bed can be made using lower temperatures than similar techniques such as spray drying. This feature constitutes a competitive advantage when considering thermally labile products (Fujita et al., 2013).

Paim et al. (2016) studied the micro-encapsulation of a probiotic Juçara juice via spray drying, using bacteria Bifidobacterium animalis ssp lactis as probiotic. The authors found a number of viable cells above $10^{6} \mathrm{CFU} / \mathrm{g}$ and high content of anthocyanins and phenolic compounds. Terpou et al. (2019) cited in their study as a strategy for increasing probiotic viability the use of encapsulants (inulin, for example) so that it is possible to achieve stability, protection from lactic oxygen-sensitive probiotic bacteria, ease of handling, transport and storage, in addition to delivery of bioactive compounds. Anekella \& Orsat (2013), found a positive correlation between the microencapsulation material concentration and the number of Lactobacillus viable cells on the powder of a probiotic raspberry juice after the spray drying process.

According to the Brazilian legislation a food to be considered probiotic must have at least $10^{8}$ a $10^{9} \mathrm{CFU} / \mathrm{g}$. However, since the spouted bed drying involves heat and shear stress to the probiotic product, a careful choice of conditions is required to maintain high cell viability in combination with high process yields. Therefore, the objective of our work was to study how the spouted bed drying conditions influence the product yield final properties of the Caja probiotic product.

\section{Materials and methods}

\subsection{Raw materials}

Caja (Spondias mobim L.) fruits used in the present work were harvested at the ripe maturation stage from the Cariri region, Paraiba, Brazil. The probiotic culture used was the Bifidobacterium animalis ssp. lactis (DELVO ${ }^{\circledR}$ PRO LAFTI B94). Inulin $\left(\mathrm{ROVAL}^{\circledR}\right)$ was used as encapsulant and maltodextrin (MOR-REX ${ }^{\circledast} 1910$ ) was used as drying adjuvant.

\subsection{Pulp production}

The Caja fruits were handpicked, sanitized with sodium hypochlorite solution at a concentration of $200 \mathrm{mg} \mathrm{L}^{-1}$ for $20 \mathrm{~min}$, and then rinsed with running water. The pulp was extracted using a $735 \mathrm{w}$ semi-industrial homogenizer at $600 \mathrm{rpm}$ (NB10, Bobina, Bahia, Brazil). The pulp was frozen at $-18{ }^{\circ} \mathrm{C}$ before further processing.

\subsection{Pulp inoculation}

Firstly, the $\mathrm{pH}$ of the pulp was set to 7.0 by adding an aqueous solution of sodium hydroxide $(\mathrm{NaOH})$. This solution is considered a food additive by (Brasil, 2007) to regulate the acidity. Using a temperature-controlled water bath (SL152/10, Solab ${ }^{\circledR}$, São Paulo, Brasil), the Caja pulp was heat-treated at $65^{\circ} \mathrm{C}$ for $20 \mathrm{~min}$. After cooling, a commercial probiotic culture was added to the pulp to a final concentration of $0.1 \%$, with $100 \mathrm{mg}$ of probiotic culture being added to each $1 \mathrm{~L}$ of pulp. The inoculation was executed aseptically using a laminar flow cabinet. The pulp was fermented for $24 \mathrm{~h}$ at $37 \pm 2{ }^{\circ} \mathrm{C}$ using the anaerobic system (Anaerobac, Probac ${ }^{\circledR}$, São Paulo, Brasil), with atmosphere generator for the anaerobic microorganism growth. All materials were previously autoclaved (CS50, Prismatec ${ }^{\circledR}$, São Paulo, Brasil)

\subsection{Drying process using spouted bed}

The drying gas inlet temperature $\left({ }^{\circ} \mathrm{C}\right)$, the maltodextrin concentration (\%) and the inulin concentration (\%) were set as independent variables of the drying process. The influence of these variables on process yield and number of viable cells as determined using an experimental design $2^{3}+3$, with three central points, resulting in 11 experiments as presented in Table1. This experimental design was chosen to model possible curvature and facilitating the investigation of a quadratic relationship between the response and the factors. A spouted bed dryer (FBD 1.0, LabMaq, São Paulo, Brasil) was used with a constant feed flow rate of $5 \mathrm{~g} / \mathrm{min}$ and an atomization pressure of $3 \mathrm{bar}$. The powdered samples were collected and stored in flexible metallic packages. The packages were sealed and stored on desiccator at room temperature.

\subsection{Determination of the process yield and number of viable cells}

The number of viable cells was determined after serial dilution of the product sample in peptone water at $1 \%(\mathrm{~m} / \mathrm{v})$, according to the methodology proposed by the international dairy federation ("ISO 20128 | IDF 192:2006") (International Organization for Standardization, 2006.). The plating was conducted using Petri dishes after deep inoculation in Agar MRS, added with L-cysteine at $0.5 \mathrm{~g} / \mathrm{L}$ (Man et al., 1960), incubated at $37 \pm 2{ }^{\circ} \mathrm{C}$ for $72 \mathrm{~h}$ in anaerobioses jars with an oxygen removal system. The results were expressed in colony formation unit per gram (CFU/g). Process yield was determined following the method described in Rocha et al. (2018) and according to Equation 1.

Table 1. Composition of the probiotic caja pulp.

\begin{tabular}{lc}
\hline \multicolumn{1}{c}{ Parameters } & Probiotic Caja pulp \\
\hline $\mathrm{pH}$ & $6.033 \pm 0.057$ \\
Total Titritable Acidity (\%Citric Acid) & $0.274 \pm 0.036$ \\
Total Soluble Solids ( ${ }^{\circ}$ Brix) & $11.333 \pm 0.288$ \\
Moisture content $(\%)$ & $87.533 \pm 0.152$ \\
Total solids $(\%)$ & $12.466 \pm 0.152$ \\
Total Phenolics $(\mathrm{mg} / \mathrm{g})$ & $185.260 \pm 0.553$ \\
Ascorbic acid (mg/gl) & $15.555 \pm 0.057$ \\
Reducing Carbohydrates $(\mathrm{mg} / \mathrm{mg})$ & $3.203 \pm 0.003$ \\
Carotenoids $(\mathrm{mg} / 100 \mathrm{~g})$ & $0.0366 \pm 0.0026$ \\
\hline
\end{tabular}

Average \pm Standard deviation 
$R=\frac{M_{c} *\left(1-X_{C}\right)}{M_{A} *\left(1-X_{A}\right)} * 100$

Where MC is the collected powder weight (g), MA is the total feed weight $(\mathrm{g}), \mathrm{XC}$ is the moisture content of the collected sample(g), and XA is the moisture content of the feed (g)

\subsection{Physicochemical and chemical characterizations of probiotic Cajá pulp and powdered probiotic Cajá pulp}

The physicochemical and chemical characterizations according to the Association of Official Analytical Chemists (2016) methods comprised the $\mathrm{pH}$, acidity, moisture content, and total solids. Reducing carbohydrates were determined according to the method proposed by (Miller, 1959). The ascorbic acid content was determined according to the methodology proposed by Keller \& Schwager (1977). The total phenolic compounds were determined by the method described by Singleton \& Rossi (1965) using the Folin-Ciocalteau reagent. The carotenoids content was determined using the Lichtenthaler (1987) method. All characterizations were repeated three times.

\subsection{Statistical analysis}

The physicochemical characterization results were subjected to a randomized design, and the average values were compared using the Tukey test at 5\% of probability, using the software Assistat 7.7 (Silva \& Azevedo, 2016). The effects of the independent variables on the dependent variables were assessed by statistical analysis using the software STATISTICA 7.0.

\section{Results and discussion}

\subsection{Physicochemical and chemical characterization of the probiotic Caja pulp}

The physicochemical and the chemical parameters of the probiotic Caja pulp after inoculation are presented in Table 1. It is observed that the $\mathrm{pH}(6.033)$ and the titratable acidity $(0.274 \%$ citric acid) are favorable values for the microorganism growth. Since the characterization was performed after the fermentation, the resulting values are a consequence of the microorganism growth (Panghal et al., 2018). This fact avoids the proliferation of other unwanted microorganisms that usually grow at lower $\mathrm{pH}$ ranges. As expected, the acidity reveals a similar but reversed behavior to $\mathrm{pH}$.

It is observed that total soluble solids have a high value $11.3^{\circ}$ Brix. This value is typical for fruit pulps and makes these excellent candidates for microorganisms growth, mostly because of the high availability of nutrients and metabolic pathways (Monteiro et al., 2020). Moreover, moisture content was also high, which is a good indication of the medium suitability for microorganism growth and a strong indication of the perishability of the fruit pulps. The chemical profile of probiotic Caja pulp revealed significant values of phenolic content, ascorbic acid, reducing carbohydrates and carotenoids. The high bioactive molecules content was expected since Caja fruit belongs to the Spondias species that generally presents fruits as sources of vitamins and bioactive compounds (Oladunjoye et al., 2021).

\subsection{Drying trials}

Table 2 summarizes the results obtained for the process yield and the number of viable cells for the 11 experiments. The statistical analysis was performed on the design of experiments. According to the data in Table 2, the inlet temperature values were 50,60 , and $70{ }^{\circ} \mathrm{C}$ and the maltodextrin and inulin concentrations were $2.5,5.0$, and $7.5 \%$.

Process yield varied from $14.34 \%$ to $23.615 \%$. Trial number 8 presented the lowest process yield. In this trial, the independent variables were $70^{\circ} \mathrm{C}$ and $7.5 \%$ for maltodextrin and inulin. Since all variables were at the maximum level, it is possible to conclude that a high quantity of inulin and maltodextrin did not bring any economic return to the process. This insight is critical for future industrialization. On the other hand, trial 4 presented the highest yield. In this trial, the temperatures and maltodextrin concentration were set at the maximum level, $70{ }^{\circ} \mathrm{C}$, and $7.5 \%$, respectively. However, inulin was set at a concentration of $2.5 \%$. Therefore, a high inulin concentration does not bring an economic return to the process.

Inulin was used as the encapsulation agent, conferring protection to the inoculated microorganism. However, considering its influence on the process yield, it is concluded

Table 2. Process yield and number of viable cells of all drying experiments.

\begin{tabular}{|c|c|c|c|c|c|}
\hline Trial & Inlet Temperature $\left({ }^{\circ} \mathrm{C}\right)$ & $\begin{array}{c}\text { Maltodextrin } \\
\text { Concentration (\%) }\end{array}$ & $\begin{array}{c}\text { Inulin Concentration } \\
(\%)\end{array}$ & Process Yield (\%) & $\begin{array}{c}\text { Number of Viable Cells } \\
(\mathrm{CFU} / \mathrm{g})\end{array}$ \\
\hline 1 & 50 & 2.5 & 2.5 & 17.863 & $1.16 \mathrm{E}+12$ \\
\hline 2 & 70 & 2.5 & 2.5 & 19.401 & $6.80 \mathrm{E}+11$ \\
\hline 3 & 50 & 7.5 & 2.5 & 19.620 & $3.72 \mathrm{E}+11$ \\
\hline 4 & 70 & 7.5 & 2.5 & 23.615 & $4.69 \mathrm{E}+11$ \\
\hline 5 & 50 & 2.5 & 7.5 & 15.457 & $2.43 \mathrm{E}+11$ \\
\hline 6 & 70 & 2.5 & 7.5 & 16.519 & $2.62 \mathrm{E}+11$ \\
\hline 7 & 50 & 7.5 & 7.5 & 15.057 & $2.76 \mathrm{E}+11$ \\
\hline 8 & 70 & 7.5 & 7.5 & 14.343 & $2.75 \mathrm{E}+11$ \\
\hline 9 & 60 & 5.0 & 5.0 & 18.770 & $4.30 \mathrm{E}+11$ \\
\hline 10 & 60 & 5.0 & 5.0 & 19.696 & $4.15 \mathrm{E}+11$ \\
\hline 11 & 60 & 5.0 & 5.0 & 18.196 & $4.22 \mathrm{E}+11$ \\
\hline
\end{tabular}


that the maximum values at $7.5 \%$ were less favorable than the minimum values at $2.5 \%$. This behavior was observed in experiments 1 to 4 , where the process yields were the highest while the inulin concentration is set at the minimum value. Additionally, in experiments 5 to 8 , the process yield was the lowest, and the inulin concentration was set at the maximum value. In experiments 9,10 and 11 , it is observed the asymmetry between the maltodextrin and the inulin at $5.0 \%$ concentration. In these trials, the process yield was in the range of the higher yields. This result was also observed by Paim et al. (2016) while studying the spray-drying of the probiotic Juçara pulp. The authors reported that a 50:50 ratio between maltodextrin and inulin yielded a more effective process. The number of viable cells found was similar throughout the 11 drying trials. Except for experiment 1, all other experiments presented exponential values of $10^{11}$. Experiment 1 had a lesser concentration of inulin and maltodextrin (2.5\%) but still presented an exponential value of $10^{12}$. This result suggests that there is a relationship between the solids content and the number of viable cells. According to Boudrant et al. (2005), high amounts of the substrate inhibit cell growth. Therefore, with a lower concentration of inulin and maltodextrin, more viable cells are found because less inhibitory action occurs. Alternatively, with high concentrations of both substrates, less viable cells are also found due to the inhibitory action. Moreover, it is observed that the inlet temperature used in experiment 1 was $50^{\circ} \mathrm{C}$. This fact corroborates that the bacterial resistance to high temperatures was also a factor in the process. Shokri et al. (2015) also found that by increasing the spray drying inlet temperature, the survival of Bifidobacterium bifidum decreased.

Nevertheless, all probiotic samples are consistent with the regulations set by Brasil (2019), and the Food and Agriculture Organization (2006), which imposes a minimum of $10^{8} \mathrm{CFU} / \mathrm{g}$ per day to be considered probiotic food products.

\subsection{Regression coefficients}

A first-order polynomial equation was fitted to the experimental data. Using ANOVA, the factors with $\mathrm{p}>0.05$ were considered non-significant and were excluded from the polynomial equation.

Table 3. Regression coefficients for process yield and number of viable cells empirical models.

\begin{tabular}{cccc}
\hline Coefficients & Variables & $\begin{array}{c}\text { Process yield } \\
(\%)\end{array}$ & $\begin{array}{c}\text { Number of } \\
\text { viable cells } \\
(\mathrm{CFU} / \mathrm{g})\end{array}$ \\
\hline$\beta_{0}$ & - & 18.049 & $4.544 \mathrm{E}+11$ \\
$\beta_{1}$ & $\mathrm{~T}_{\text {in }}$ & $\mathrm{NS}$ & $\mathrm{NS}$ \\
$\beta_{2}$ & $\mathrm{C}_{\text {MALTO }}$ & $\mathrm{NS}$ & $-1.185 \mathrm{E}+11$ \\
$\beta_{3}$ & $\mathrm{CINU}$ & -2.390 & $-2.026 \mathrm{E}+11$ \\
$\beta_{4}$ & $\mathrm{~T}_{\text {in }} \cdot \mathrm{C}_{\text {MALTO }}$ & $\mathrm{NS}$ & $\mathrm{NS}$ \\
$\beta_{5}$ & $\mathrm{~T}_{\text {in }} \cdot$ C $_{\text {INU }}$ & $\mathrm{NS}$ & $\mathrm{NS}$ \\
$\beta_{6}$ & $\mathrm{CMALTO} \mathrm{C}_{\mathrm{INU}}$ & $\mathrm{NS}$ & $1.299 \mathrm{E}+11$ \\
$\mathrm{R}^{2}$ & - & 65.017 & 82.452 \\
$\mathrm{~F}$ & - & 16.726 & 10.963 \\
\hline$\beta_{0}-\beta_{7}$ & - &
\end{tabular}

$\beta_{0}-\beta_{7}=$ Regression coefficients; $R^{2}=$ coefficient of determination; $T_{\text {in }}=$ Inlet Temperature; $\mathrm{C}_{\text {MALTO }}=$ Maltodextrin concentration; $\mathrm{C}_{\mathrm{INU}}=$ Inulin concentration; $\mathrm{NS}=$ Not significative for $\mathrm{p}<0.05$.
Then a new fitting was performed using only the significant factors. The results are summarized in Table 3 .

The parameter $\beta_{0}$ is representing the average value of all trials for both dependent variables. Process yield (R) is considered low. However, since the process is on the development stage, it can be considered acceptable (Bhandari et al., 1997). Moreover, the probiotic pulp has low molecular weight compounds, especially after fermentation. These low molecular weight compounds, such as reducing sugars or acids, have low glass transition temperatures resulting in powders that stick to dryer chamber walls (Tontul \& Topuz, 2017). The number of viable cells presented an average value above the recommended daily dose determined by legislation (ANVISA and FAO). Therefore, the Caja pulp is a favorable medium for the growth and preservation of the microorganism viable cells.

The inlet temperature has no significative $(\mathrm{p}>0.05)$ influence on the dependent variables. This result reveals the small influence of the drying temperature on both yield and the number of viable cells. Maltodextrin concentration revealed a negative correlation with the number of viable cells. This negative correlation means that increasing maltodextrin concentration results in a lesser number of viable cells. Shokri et al. (2015) also found a negative correlation between maltodextrin concentration and the probiotic bacteria survival. This result is considered positive as it demonstrates that using large quantities of maltodextrin does not influence the desired number of viable cells. Additionally, the maltodextrin concentration was not statistically significant $(p>0.05)$ for the process yield. Inulin concentration negatively influenced both the process yield and the number of viable cells. This result reveals that a larger quantity of additives can reduce the process yield. Additionally, since the inulin is an additive with the function to protect the microorganism, the result suggests that an excessive number of nutrients can result in a more competitive medium and lead to cell death.

The interaction between maltodextrin and inulin was the only parameter statistically significant $(\mathrm{p}<0.05)$ among all interactions. The combination of maltodextrin and inulin positively influenced the number of viable cells, increasing the average number of viable cells when the concentration of both polysaccharides is increased. This result suggests that an equilibrium between the drying adjuvant and the encapsulation material results in higher cell resistance when submitted to the drying process.

The resulting polynomial equation for the process yield presented a coefficient of determination of 65.017, which is considered low. However, this result is justifiable since this process variable is directly associated with the spouted drying process, which is a complex technique where several other variables must be adjusted for a better outcome. Additionally, the re-parametrization minimized the correlation and the relative errors of the parameter's estimation.

The polynomial equation fitted to the number of viable cells (NCV) results presented a $\mathrm{R}^{2}$ of 82.45. Even though this result reveals a better fit, the application of mathematical models to living organisms and its behavior can result in a mismatch due to the conditions imposed by the process.

Furthermore, the F test is a statistical test used to prove which factors and interactions are statistically significant in 
the process. Thus, the $\mathrm{F}$ test is of fundamental importance to understand the behavior of the dependent variable. To do so, the $\mathrm{F}$ is calculated using ANOVA and compared to the F tabulated determined by the degrees of freedom observed in each dependent variable and for a specific probability range. For process yield, the calculated $\mathrm{F}$ was 16.72 for a probability below $5 \%(\mathrm{p}<0.05)$, while the tabulated $\mathrm{F}$ was 5.12 also for a $p<0.05$. As for the number of viable cells, the $F$ calculated was 10.96 , and the F tabulated was 4.35 . Thus, for both dependent variables, the $\mathrm{F}$ test presented values above the tabulated value, and therefore both are statistically significant for $\mathrm{p}<0.05$. The degrees of freedom presented different values, and the $\mathrm{R}^{2}$ values were low due to the parameterization performed to optimize the parameters and better fit them to the polynomial model.

\subsection{Response surfaces}

Response surfaces are an effective method to predict the optimal process conditions. According to Rodrigues \& Iemma (2014), in a design of experiments, the response surfaces should only be generated if the ANOVA reveals that a given variable is statistically significant. Thus, since both variables are statistically significant for $\mathrm{p}<0.05$, then the surface responses were generated to identify the general trends of the process and the regions of interest. Figure 1 presents the three surfaces responses for the process yield.
Figure 1A presents the surface response of inulin concentration in combination with the inlet temperature while the maltodextrin concentration is fixed at the central point (5.0\%). It is observed that the lower the concentration of inulin, the higher the process yield is, for temperatures above $58{ }^{\circ} \mathrm{C}$. However, the highest value for the process yield is observed for low concentrations of inulin and high inlet temperatures, resulting in experiment 4 , as presented in Table 2 (23.615\%).

Figure $1 \mathrm{~B}$ presents the surface response of maltodextrin concentration along with the inlet temperature. The highest process yield was obtained for the highest concentration of maltodextrin and the highest inlet temperature. It is observed that above $66^{\circ} \mathrm{C}$, the lower maltodextrin concentrations resulted in higher yield values, which is a similar behavior when comparing the higher maltodextrin concentrations above $56^{\circ} \mathrm{C}$. Nevertheless, considering both variables slopes, the inlet temperature is more influential on process yield than the maltodextrin concentration.

Figure $1 \mathrm{C}$ presents the surface response of the maltodextrin and inulin interaction, with the inlet temperature fixed at $60^{\circ} \mathrm{C}$. It can be observed that the highest yields are achieved when the inulin concentration is at its lower values and the maltodextrin concentration at its highest values.

Figure 2 presents three surfaces response to the number of viable cells. Figure $2 \mathrm{~A}$ shows the effects of inulin concentration
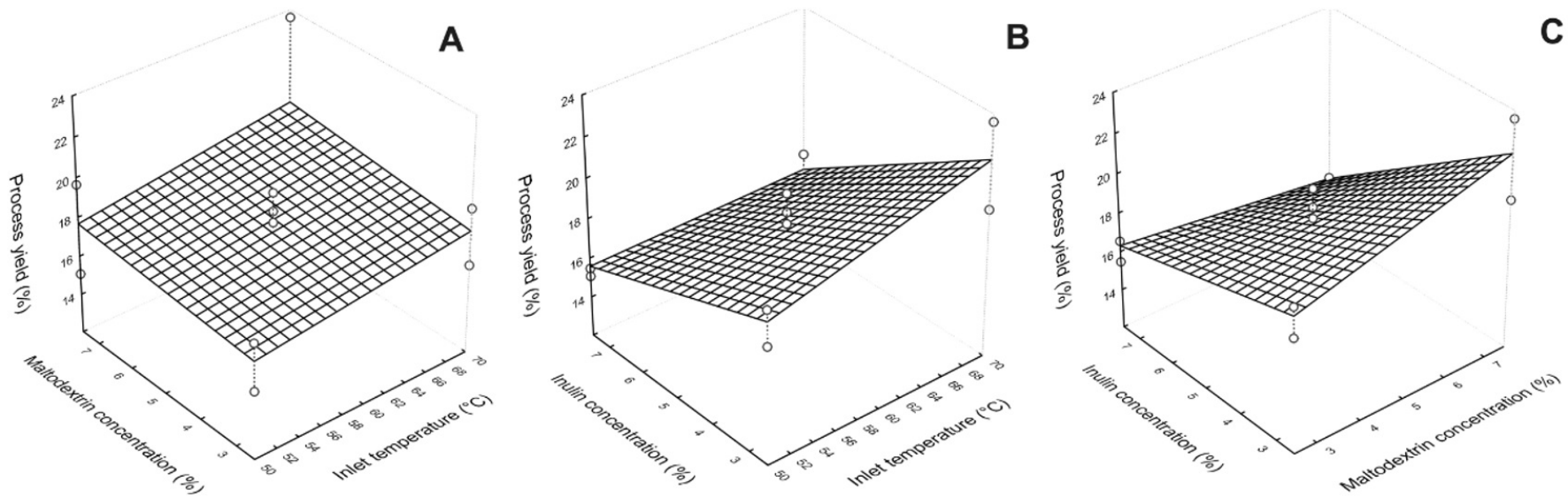

Figure 1. Response surface for process yield: (A) maltodextrin concentration at $5 \%$; (B) inulin concentration at $5 \%$; (C) inlet temperature at $60{ }^{\circ} \mathrm{C}$.
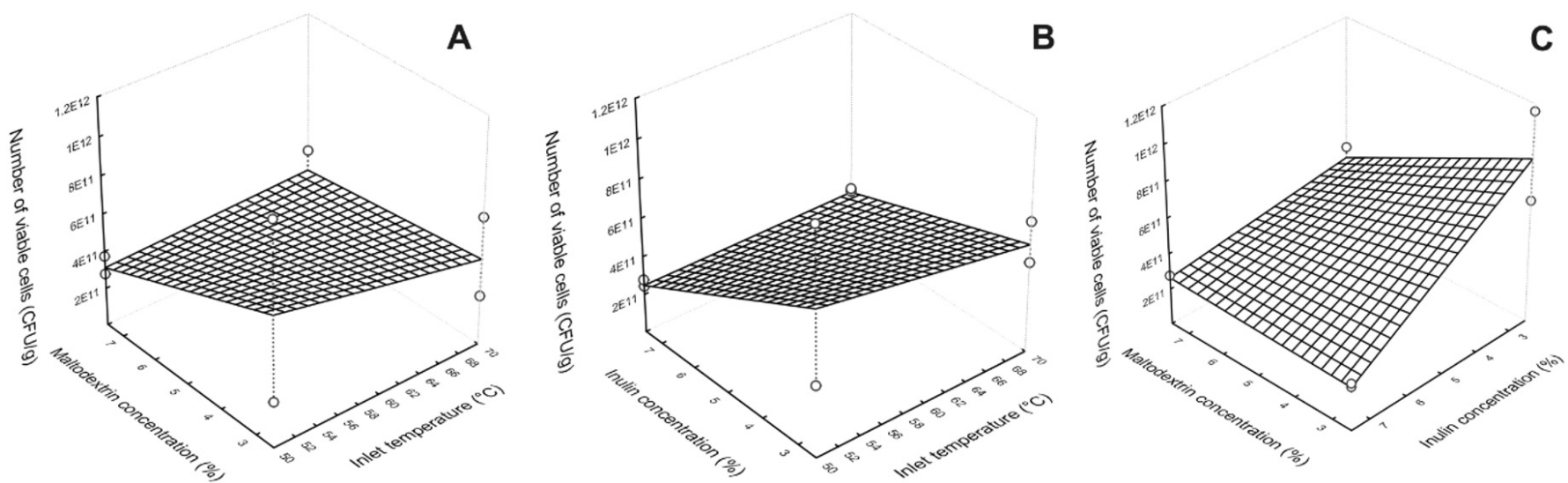

Figure 2. Response surface for number of viable cells: (A) maltodextrin at 5\%; (B) inulin concentration at 5\%; (C) inlet temperature at $60{ }^{\circ} \mathrm{C}$. 


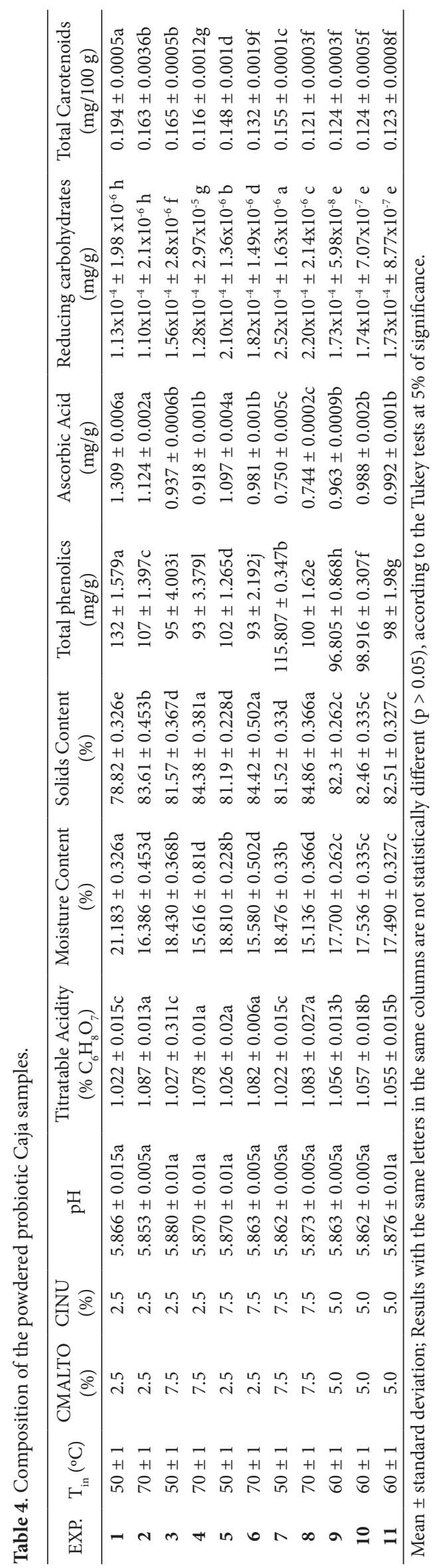


and the inlet temperature when the maltodextrin concentration is fixed at $5.0 \%$, and Figure $2 \mathrm{~B}$ the effects of the maltodextrin concentration and the inlet temperature when the inulin concentration if fixed at $5.0 \%$.

The behavior of the number of viable cells observed in these two response surfaces can be explained as follow: a lower concentration of inulin (Figure $2 \mathrm{~A}$ ) and maltodextrin (Figure 2B), separately, make the medium less competitive and consequently a higher number of bacteria can survive. However, when using a maximum level of both inulin and maltodextrin, it is observed a process trend to have less viable cells. This fact is independent of the inlet temperature. On Figure 2A, it is observed that inulin increases the temperature threshold up to $68^{\circ} \mathrm{C}$, and only above this temperature, less viable cells are obtained. Alternatively, according to Figure $2 \mathrm{~B}$, maltodextrin only increases the temperature threshold to $58^{\circ} \mathrm{C}$. The combination of both parameters is the experiment $1\left(1.16 \times 10^{12} \mathrm{CFU} / \mathrm{g}\right)$. Figure $2 \mathrm{C}$ presents the number of viable cells as a function of maltodextrin and inulin concentration at a fixed temperature $\left(60^{\circ} \mathrm{C}\right)$. It is observed that the number of viable cells increases with the reduction of both concentrations. This result indicates that the drying process does not require high quantities of additives to obtain a product with a high number of viable cells.

\subsection{Physicochemical characterizations of the powdered probiotic Caja pulp}

The physicochemical and chemical characterizations were performed to evaluate the alterations caused by the drying process. Table 4 summarizes all results from the characterizations.

$\mathrm{pH}$ is a parameter that is directly linked to bacteria survival by avoiding the proliferation of unwanted microorganisms and their exponential phase. Thus, $\mathrm{pH}$ should be observed with caution because the optimal range for growth is between 6.5 and 7.0. According to Butel (2014), a reduction of bacterial growth occurs for $\mathrm{pH}$ below 5.0. Therefore, the powdered samples are still in favorable conditions for microbial survival. No statistical difference was found by the Tukey test, which means that process variables did not influence the $\mathrm{pH}$ of the final product. Moreover, the final $\mathrm{pH}$ is also statistically equal to the liquid probiotic pulp.

The drying temperature was the variable that most influenced titratable acidity. A significant difference was found between samples dried with different inlet temperatures. Moreover, it was observed an increase in TTA when the inlet temperature was also increased. This result indicates that the more dehydrated the powder is, the more concentrated compounds such as organic acids are, and thereby an increase in acidity is observed (Nunes et al., 2017). This result is confirmed when the liquid pulp acidity is compared to the acidity of the powdered pulp.

Moisture content presented a negative correlation with inlet temperature since the lower moisture content values were found for the highest temperatures $\left(70^{\circ} \mathrm{C}\right)$. Consequently, the samples with the highest moisture content presented lower solids content. The probiotic pulp presents a high resistance to elevated temperatures as evidenced by the survival of Bifidobacterium animalis ssp. lactis. According to Butel (2014), the microorganism duplicates its growth for temperatures between $20^{\circ} \mathrm{C}$ to $46^{\circ} \mathrm{C}$, and starts its decline or die at $60^{\circ} \mathrm{C}$. Thus, our work was more focused on interconnecting the microorganism's survival to product quality. However, the results were satisfactory for moisture contents in the range of 15.1 to $21.1 \%$ and 78.8 to $84.9 \%$ for solids content. All results presented were statistically different, considering the probability of $5 \%$. Similar results were found by Alves et al. (2017) while drying Caja pulp using spouted bed and similar inlet temperatures. Moreover, the maltodextrin and inulin concentrations also contributed to the solids content, since higher solids content was found for the samples with higher additives concentration.

Phenolic compounds add several properties to the food, including antioxidant, antimicrobial and anti-inflammatory. However, even though there is no recommended dosage, the phenolic content should be high to guarantee its efficiency (Fernández et al., 2018). A decrease in phenolic contents was found when comparing the dried samples to the liquid probiotic pulp. This result indicates that the phenolic compounds were exposed to enough heat to degrade some of the bioactive molecules. However, some samples still presented considerable amounts of phenolic compounds, as sample 1 and 7, with $137.8 \mathrm{mg} / \mathrm{g}$ and $115.8 \mathrm{mg} / \mathrm{g}$, respectively. Both samples were dried with the lower inlet temperature but with different contents of maltodextrin and inulin. Therefore, the concentrations of both additives did not present any influence on the phenolic content. All results presented significant differences $(\mathrm{p}<0.05)$, and varied between $93.266 \mathrm{mg} / \mathrm{g}$ (experiment 4) and $132.783 \mathrm{mg} / \mathrm{g}$ (experiment 1).

The ascorbic acid content on the powdered samples presented a much lower value when compared to the Caja pulp (15.555 $\mathrm{mg}$ ascorbic acid/g). A similar trend was found in the corresponding phenolic content. The ascorbic content presented values ranging from $0.744 \mathrm{mg} / \mathrm{g}$ to $1.309 \mathrm{mg} / \mathrm{g}$, with all values being statistically significant $(\mathrm{p}<0.05)$.

The temperature effect on the bioactive compounds can be corroborated. The samples with higher bioactive contents are the samples obtained with a lower inlet temperature for the same maltodextrin and inulin concentration. Moreover, the experiments with a higher concentration of inulin and maltodextrin (experiments 7 and 8) presented the lower ascorbic content, thereby presenting a negative correlation. This result suggests a decrease in the stability of the bioactive compounds when high amounts of additives are used.

Reducing carbohydrates also presented a reduction when compared to the liquid probiotic pulp. The values ranged from $1.1 \times 10^{-4}$ to $2.5 \times 10^{-4} \mathrm{mg} / \mathrm{g}$, and all results presented a significant difference $(p<0.05)$. Samples with a higher concentration of maltodextrin and inulin (experiments 7 and 8), presented higher reducing carbohydrates values. This result suggests that these two high molecular weight carbohydrates can be digested by the bacteria enzymes into smaller sugars and thus resulting in the presence of higher reducing carbohydrates. This suggestion is supported by the fact that samples with a lower concentration of additives also present a lower concentration of reducing sugars.

Carotenoids are a group of natural dyes with biological activity that promotes health benefits due to the presence of the pro-vitamin A and antioxidants (Mesquita et al., 2017). Thus, 
the presence of this carotenoid on the final powder is considered critical for the product value. Powdered samples dried with an inlet temperature of $70^{\circ} \mathrm{C}$ presented a reduction in carotenoid content, indicating degradation by heat exposure. Alternatively, in experiments 1 and 2 , the inlet temperature was set to $50^{\circ} \mathrm{C}$, and the carotenoid content was 0.194 and $0.163 \mathrm{mg} / \mathrm{g}$, which are the highest contents. This result indicates that the carotenoids are thermally labile and that higher temperatures will result in its loss. The maltodextrin and inulin concentrations did not present any specific trend regarding the carotenoid content. The results presented a significant difference $(\mathrm{p}<0.05)$.

\section{Conclusion}

Probiotic Caja pulp was successfully converted into a powdered probiotic product with a high number of viable cells that met the Brazilian legislation. The present work used a design of experiments to identify the best conditions to produce a fruit probiotic powder using a spouted bed dryer. Considering the cell viability and the bioactive compounds as the most relevant properties of the product, the results revealed that by using less maltodextrin and inulin, along with lower temperatures, the process would provide a better economic return. Finally, and due to the high cell viability, it is highlighted the potentiality of the product as a health promoter.

\section{References}

Albuquerque, A. P., Rodrigues, T. J. A., Cavalcante Neto, J. L., \& Rocha, A. P. T. (2021). Utilization of powdered fruit pulp probiotic loaders as a functional food: general aspects and perspectives. Brazilian Journal of Food Technology, 24, e2019310.

Alves, N. N., de Oliveira Sancho, S., da Silva, A. R. A., Desobry, S., da Costa, J. M. C., \& Rodrigues, S. (2017). Spouted bed as an efficient processing for probiotic orange juice drying. Food Research International, 101, 54-60. http://dx.doi.org/10.1016/j. foodres.2017.08.052. PMid:28941697.

Anekella, K., \& Orsat, V. (2013). Optimization of microencapsulation of probiotics in raspberry juice by spray drying. $L W T, 50(1), 17-24$. http://dx.doi.org/10.1016/j.lwt.2012.08.003.

Association of Official Analytical Chemists - AOAC. (2016). Official Methods of Analysis of AOAC International (20th ed.). Rockville: AOAC International.

Bhandari, B. R., Datta, N., \& Howes, T. (1997). Problems associated with spray drying of sugar-rich foods. Drying Technology, 15(2), 671-684. http://dx.doi.org/10.1080/07373939708917253.

Boudrant, J., Menshutina, N. V., Skorohodov, A. V., Guseva, E. V., \& Fick, M. (2005). Mathematical modelling of cell suspension in high cell density conditions: application to L-lactic acid fermentation using Lactobacillus casei in membrane bioreactor. Process Biochemistry, 40(5), 1641-1647. http://dx.doi.org/10.1016/j.procbio.2004.06.051.

Brasil, Agência Nacional de Vigilância Sanitária - ANVISA. (2019). Alimentos com Alegação de Propriedades Funcionais e ou de Saúde, Novos Alimentos/Ingredientes, Substâncias Bioativas e Probióticos. Agência Nacional de Vigilância Sanitária. Retrieved from https:// www.gov.br/agricultura/pt-br/assuntos/inspecao/produtos-vegetal/ legislacao-1/biblioteca-de-normas-vinhos-e-bebidas/alegacoes-depropriedade-funcional-aprovadas_anvisa.pdf

Brasil, Agência Nacional de Vigilância Sanitária - ANVISA. (2007). Informe Técnico n³3, de 25 de outubro de 2007. Hidróxido de sódio - INS 524. Relatório de Atividades GGALI. Retrieved from http://portal.anvisa.gov.br/resultado-de-busca?p_p_id=101\&p_p_ lifecycle $=0 \& p \_p \_s t a t e=$ maximized\&p_p_mode $=$ view\&p_p_col_ id=column-\&p_p_col_count=1\&_101_struts_action=\%2Fasset publisher\%2Fview_content\&_101_assetEntryId=2775154\&_101_ type $=$ content\&_101_groupId=33916\&_101_urlTitle=informetecnico-n-33-de-25-de-outubro-de-2007\&inheritRedirect=true

Butel, M. J. (2014). Probiotics, gut microbiota and health. Medecine et Maladies Infectieuses, 44(1), 1-8. http://dx.doi.org/10.1016/j. medmal.2013.10.002. PMid:24290962.

Chaves, J. R. No. (2019). Aspectos de qualidade de frutos de cajámangueira: uma revisão. Revista Científica Rural, 21(1), 111-130.

Dincer, E., \& Kivanc, M. (2020). Characterization of Lactobacillus plantarum strains isolated from Turkish pastırma and possibility to use of food industry. Food Science and Technology, 40(2), 498-507. http://dx.doi.org/10.1590/fst.05819.

Fernández, M. A., Espino, M., Gomez, F. J., \& Silva, M. F. (2018). Novel approaches mediated by tailor-made green solvents for the extraction of phenolic compounds from agro-food industrial byproducts. Food Chemistry, 239, 671-678. http://dx.doi.org/10.1016/j. foodchem.2017.06.150. PMid:28873620.

Ferreira, S., Araujo, T., Souza, N., Rodrigues, L., Lisboa, H. M., Pasquali, M., Trindade, G., \& Rocha, A. P. (2019). Physicochemical, morphological and antioxidant properties of spray-dried mango kernel starch. Journal of Agriculture and Food Research, 1, 100012. http://dx.doi.org/10.1016/j.jafr.2019.100012.

Food and Agriculture Organization - FAO, World Health Organization - WHO. (2002). Guidelines for the evaluation of probiotics in food: report of a joint $\mathrm{FAO} / \mathrm{WHO}$ working group on drafting guidelines for the evaluation of probiotics in food. London: $\mathrm{FAO} / \mathrm{WHO}$.

Food and Agriculture Organization - FAO, World Health Organization - WHO. (2006). Probiotics in food: health and nutritional properties and guidelines for evaluation: report of a joint FAO/WHO. Rome: $\mathrm{FAO} / \mathrm{WHO}$.

Fujita, A., Borges, K., Correia, R., Franco, B. D. G. M., \& Genovese, M. I. (2013). Impact of spouted bed drying on bioactive compounds, antimicrobial and antioxidant activities of commercial frozen pulp of camu-camu (Myrciaria dubia Mc. Vaugh). Food Research International, 54(1), 495-500. http://dx.doi.org/10.1016/j.foodres.2013.07.025.

International Organization for Standardization - ISO. (2006). ISO 20128 | IDF 192:2006: Milk products - enumeration of presumptive Lactobacillus acidophilus on a selective medium - colony-count technique at $37{ }^{\circ} \mathrm{C}$. Geneva: ISO. Retrieved from https://www.iso. org/standard/35292.html

Joshi, D., Roy, S., \& Banerjee, S. (2018). Prebiotics: a functional food in health and disease. In S. C. Mandal, V. Mandal \& T. Konishi (Eds.), Natural products and drug discovery, (pp. 507-523). Amsterdam: Elsevier.

Keller, T., \& Schwager, H. (1977). Air pollution and ascorbic acid. European Journal of Forest Pathology, 7(6), 338-350. http://dx.doi. org/10.1111/j.1439-0329.1977.tb00603.x.

Lichtenthaler, H. K. (1987). Chlorophyll and carotenoids-pigments of photosynthetic biomembranes. In B. Tian (Ed.). Methods in enzymology (pp. 350-382). San Diego: Elsevier Academic Press. http://dx.doi.org/10.1016/0076-6879(87)48036-1.

Man, J. C., Rogosa, D., \& Sharpe, M. E. (1960). A medium for the cultivation of lactobacilli. The Journal of Applied Bacteriology, 23(1), 130-135. http://dx.doi.org/10.1111/j.1365-2672.1960.tb00188.x.

Mattietto, R. A., \& Matta, V. M. (2011). Cajá (Spondias mombin L.). In E. M. Yahia (Ed.), Postharvest biology and technology of tropical 
and subtropical fruits (pp. 330-351). Sawston: Woodhead Publishing. http://dx.doi.org/10.1533/9780857092762.330

Mesquita, S. D. S., Teixeira, C. M., \& Servulo, E. F. (2017). Carotenoids: properties, applications and market. Revista Virtual de Química, 9(2), 672-688.

Miller, G. L. (1959). Use of dinitrosalicylic acid reagent for determination of reducing sugar. Analytical Chemistry, 31(3), 426-428. http://dx.doi. org/10.1021/ac60147a030.

Monteiro, S. S., Beserra, Y. A. S., Oliveira, H. M. L., \& Pasquali, M. A. B. (2020). Production of probiotic passion fruit (Passiflora edulis Sims f. flavicarpa Deg.) drink using Lactobacillus reuteri and microencapsulation via spray drying. Foods, 9(3), 335. http://dx.doi. org/10.3390/foods9030335. PMid:32178366.

Nunes, J. S., Lins, A. D. F., Gomes, J. P., Silva, W. D., \& Silva, F. D. (2017). Influência da temperatura de secagem nas propriedades físicoquímica de resíduos abacaxi. Revista Agropecuária Técnica, 1(1), 41-46.

Oladunjoye, A. O., Adeboyejo, F. O., Okekunbi, T. A., \& Aderibigbe, O. R. (2021). Effect of thermosonication on quality attributes of hog plum (Spondias mombin L.) juice. Ultrasonics Sonochemistry, 70, 105316. http://dx.doi.org/10.1016/j.ultsonch.2020.105316. PMid:32889410.

Paim, D. R., Costa, S. D., Walter, E. H., \& Tonon, R. V. (2016). Microencapsulation of probiotic jussara (Euterpe edulis M.) juice by spray drying. $L W T, 74,21-25$. http://dx.doi.org/10.1016/j. lwt.2016.07.022.

Panghal, A., Janghu, S., Virkar, K., Gat, Y., Kumar, V., \& Chhikara, N. (2018). Potential non-dairy probiotic products-a healthy approach. Food Bioscience, 21, 80-89. http://dx.doi.org/10.1016/j.fbio.2017.12.003.

Rocha, A. P. T., Lisboa, H. M., Alsina, O. L. S., \& Silva, O. S. (2018). Coating process of Phyllanthus niruri Linn granules using spouted bed. Powder Technology, 336, 85-91. http://dx.doi.org/10.1016/j. powtec.2018.05.052.
Rodrigues, M. I., \& Iemma, A. F. (2014). Planejamento de experimentos e otimização de processos (2a ed.). Campinas: Casa do Pão Editora.

Rusu, E., Enache, G., Cursaru, R., Alexescu, A., Radu, R., Onila, O., Cavallioti, T., Rusu, F., Posea, M., Jinga, M., \& Radulian, G. (2019). Prebiotics and probiotics in atopic dermatitis. Experimental and Therapeutic Medicine, 18(2), 926-931. PMid:31384325.

Shokri, Z., Fazeli, M. R., Ardjmand, M., Mousavi, S. M., \& Gilani, K. (2015). Factors affecting viability of Bifidobacterium bifidum during spray drying. Daru : Journal of Faculty of Pharmacy, 23(1), 7. http://dx.doi.org/10.1186/s40199-014-0088-z. PMid:25618319.

Silva, C. F. G. D., Santos, F. L., Santana, L. R. R. D., Silva, M. V. L., \& Conceicao, T. D. A. (2018). Development and characterization of a soymilk Kefir-based functional beverage. Food Science and Technology, 38(3), 543-550. http://dx.doi.org/10.1590/1678-457x.10617.

Silva, F. A. S., \& Azevedo, C. A. V. (2016). The Assistat Software Version 7.7 and its use in the analysis of experimental data. African Journal of Agricultural Research, 11(39), 3733-3740. http://dx.doi.org/10.5897/ AJAR2016.11522.

Singleton, V. L., \& Rossi, J. A. (1965). Colorimetry of total phenolics with phosphomolybdic-phosphotungstic acid reagents. American Journal of Enology and Viticulture, 16(3), 144-158.

Terpou, A., Papadaki, A., Lappa, I. K., Kachrimanidou, V., Bosnea, L. A., \& Kopsahelis, N. (2019). Probiotics in food systems: significance and emerging strategies towards improved viability and delivery of enhanced beneficial value. Nutrients, 11(7), 1591. http://dx.doi. org/10.3390/nu11071591. PMid:31337060.

Tontul, I., \& Topuz, A. (2017). Spray-drying of fruit and vegetable juices: effect of drying conditions on the product yield and physical properties. Trends in Food Science \& Technology, 63, 91-102. http:// dx.doi.org/10.1016/j.tifs.2017.03.009. 